\title{
Properties and Physiologic Roles of the Plasma Membrane Sodium-Hydrogen Exchanger
}

\author{
Julian L. Seifter and Peter S. Aronson \\ Laboratory of Kidney and Electrolyte Physiology, Brigham and Women's Hospital and Department of Medicine, Harvard Medical School \\ Boston, Massachusetts 02115; Departments of Medicine \\ and Physiology, Yale University School of Medicine, New Haven, Connecticut 06510
}

\section{Introduction}

A necessary function of all eukaryotic cells is the regulation of intracellular $\mathrm{pH}$. Because the typical cell has a large inside-negative membrane potential, a passive distribution of $\mathrm{H}^{+}$across the plasma membrane would create an acid intracellular $\mathrm{pH}$ $\left(\mathrm{pH}_{\mathrm{i}}\right)^{1}$ that would be incompatible with normal metabolic function (1). Each cell therefore requires a mechanism for the uphill extrusion of $\mathrm{H}^{+}$into the extracellular fluid. In some cells this process of $\mathrm{H}^{+}$secretion is accomplished by an $\mathrm{H}^{+}$-ATPase directly coupling active $\mathrm{H}^{+}$secretion to ATP hydrolysis (2). In the snail neuron (3) and giant axon of the squid (4) $\mathrm{pH}_{\mathrm{i}}$ regulation involves a mechanism coupling $\mathrm{Na}^{+}$and $\mathrm{HCO}_{3}^{-}$transport into the cell to the efflux of $\mathrm{Cl}^{-}$, a process stimulated by cellular acidification and inhibited by anion transport inhibitors.

Another cellular mechanism for active $\mathrm{H}^{+}$secretion is $\mathrm{Na}^{+}$$\mathrm{H}^{+}$countertransport. The $\mathrm{Na}^{+}$concentration in the cell is maintained well below that of the extracellular fluid by the active removal of $\mathrm{Na}^{+}$via $\mathrm{Na}^{+}-\mathrm{K}^{+}$ATPase. The thermodynamic driving force for $\mathrm{H}^{+}$extrusion in coupled $\mathrm{Na}^{+}-\mathrm{H}^{+}$exchange is the energy of the inwardly directed electrochemical $\mathrm{Na}^{+}$gradient. This type of ion gradient-driven transport process, which has only an indirect requirement for metabolic energy, is referred to as secondary active transport (5).

The plasma membrane $\mathrm{Na}^{+}-\mathrm{H}^{+}$exchanger has three important functions that are interrelated. First, the exchanger regulates intracellular $\mathrm{pH}$ and thereby regulates those cellular metabolic processes that are dependent on $\mathrm{pH}_{\mathrm{i}}$. In this regard the $\mathrm{Na}^{+}-\mathrm{H}^{+}$ exchanger is an important intermediate between some extracellular hormones and metabolic events such as protein and DNA synthesis and glycolysis (1). Second, $\mathrm{Na}^{+}-\mathrm{H}^{+}$exchange serves as an important cell entry mechanism for $\mathrm{Na}^{+}$. In addition to the possible requirement of metabolic reactions for cell $\mathrm{Na}^{+}$, the net solute influx will have important consequences on distribution of water between cells and the extracellular space, thus

Address reprint requests to Dr. Seifter, Laboratory of Kidney and Electrolyte Physiology, Brigham and Women's Hospital, 75 Francis Street, Boston, MA 02115.

Received for publication 1 April 1986.

1. Abbreviations used in this paper: DCCD, N,N'-dicyclohexylcarbodiimide; EEDQ, ethoxy-carbonyl-ethoxy-dihydroquinoline; EGF, epidermal growth factor; $K_{\mathrm{i}}$, inhibition constant; PDGF, platelet-derived growth factor; $\mathrm{pH}_{\mathrm{i}}$, intracellular $\mathrm{pH}$; $\mathrm{SH}$, sulfhydryl; $\mathrm{V}_{\max }$, maximum velocity.

J. Clin. Invest.

(C) The American Society for Clinical Investigation, Inc.

0021-9738/86/10/0859/06 \$1.00

Volume 78, October 1986, 859-864 contributing to cell volume regulation (6). A third category of functions attributed to $\mathrm{Na}^{+}-\mathrm{H}^{+}$exchange is found in epithelial cells, specialized to accomplish net transport of solutes between the extracellular fluid and a transcellular space, such as intestinal, gall bladder, and renal tubular lumena (7-9). In this case, cellular $\mathrm{H}^{+}$secretion may contribute to net $\mathrm{H}^{+}$excretion from the body or to a change in $\mathrm{pH}$ of the transcellular fluid contents. $\mathrm{Na}^{+}-\mathrm{H}^{+}$ exchange may also contribute to net transepithelial $\mathrm{Na}^{+}$transport. With net $\mathrm{Na}^{+}$transport, the process of $\mathrm{Na}^{+}$entry is often accompanied by the simultaneous movement of an anionic species. Hormones regulating urinary acid excretion or extracellular fluid volume may work through $\mathrm{Na}^{+}-\mathrm{H}^{+}$exchange.

In addition to the roles of $\mathrm{Na}^{+}-\mathrm{H}^{+}$exchange in normal cell function there is evidence for adaptive changes in transport activity during pathophysiologic states of electrolyte, acid-base, or hormonal imbalance of the organism. The purpose of this review is to describe the properties of the $\mathrm{Na}^{+}-\mathrm{H}^{+}$exchanger; to summarize its diverse contributions to normal cell function; to describe the mechanisms by which the activity of the $\mathrm{Na}^{+}-\mathrm{H}^{+}$exchanger is regulated, and to discuss a potential role for this transporter in certain pathophysiologic states.

Properties of the $\mathrm{Na}^{+}-\mathrm{H}^{+}$exchanger. $\mathrm{Na}^{+}-\mathrm{H}^{+}$exchange has been identified in many cell preparations and in cell culture, and has been characterized with respect to such general transport properties as stoichiometry for $\mathrm{Na}^{+}$and $\mathrm{H}^{+}$transfer, cation specificity, and inhibitor sensitivity. The transport properties of the exchanger have been most extensively determined in purified microvillus membrane vesicles isolated from the renal cortex. $\mathrm{Na}^{+}$influx in these vesicles is stimulated by outwardly directed $\mathrm{H}^{+}$gradients and $\mathrm{H}^{+}$outflux is stimulated by inwardly directed $\mathrm{Na}^{+}$gradients $(7,10)$. Both of these processes are unaltered by membrane potential differences indicating electroneutral $\mathrm{Na}^{+}$ for $\mathrm{H}^{+}$exchange $(7,10)$. Imposition of outwardly directed $\mathrm{Na}^{+}$ gradients, thermodynamically balanced by outwardly directed $\mathrm{H}^{+}$gradients of equivalent magnitude, abolishes net $\mathrm{Na}^{+}$uptake suggesting a stoichiometric ratio of $1 \mathrm{Na}^{+}: 1 \mathrm{H}^{+}(11)$. Vesicle $\mathrm{Na}^{+}$ uptake follows simple saturation kinetics with respect to external $\mathrm{Na}^{+}$concentration, indicating a single external binding site for $\mathrm{Na}^{+}$, consistent with a stoichiometry of $1 \mathrm{Na}^{+}: 1 \mathrm{H}^{+}$transported (9). $\mathrm{Na}^{+}$uptake stimulated by outwardly directed $\mathrm{H}^{+}$gradients is inhibited by external addition of $\mathrm{Li}^{+}$and $\mathrm{NH}_{4}^{+}$demonstrating affinity for these cations, whereas $\mathrm{K}^{+}, \mathrm{Rb}^{+}$, and $\mathrm{Cs}^{+}$cannot substitute for $\mathrm{Na}^{+}(12)$. In addition to $\mathrm{Na}^{+}-\mathrm{H}^{+}$exchange, the transporter can operate in other modes involving these cations, such as $\mathrm{Li}^{+}-\mathrm{H}^{+}$exchange, $\mathrm{Na}^{+}-\mathrm{Na}^{+}$exchange, and $\mathrm{Na}^{+}-\mathrm{NH}_{4}^{+}$exchange. The effect of external $\mathrm{Li}^{+}, \mathrm{NH}_{4}^{+}$, and $\mathrm{H}^{+}$on $\mathrm{Na}^{+}$uptake is competitive in nature and can be explained by a single external binding site for these cations. For example decreasing external 
$\mathrm{pH}$ from 7.5 to 6.6 results in an increase in apparent Michaelis constant $\left(K_{\mathrm{m}}\right)$ for $\mathrm{Na}^{+}$from 13 to $54 \mathrm{mM}$ without an effect on maximum velocity $\left(\mathrm{V}_{\max }\right)(13)$. In contrast, rates of $\mathrm{Na}^{+}$uptake do not increase as a simple function of increasing internal $\left[\mathrm{H}^{+}\right]$ (14). Instead, the rate of $\mathrm{Na}^{+}$influx at varied internal $\mathrm{pH}$ shows greater than first-order dependence on internal $\left[\mathrm{H}^{+}\right]$. At constant external $\mathrm{pH}$ of 7.5 , net $\mathrm{Na}^{+}$efflux via $\mathrm{Na}^{+}-\mathrm{H}^{+}$exchange increases threefold as internal $\mathrm{pH}$ is decreased from 7.5 to 6.9 , despite a decrease in the net thermodynamic driving force for $\mathrm{Na}^{+}$efflux via countertransport. Given the stoichiometry of $1 \mathrm{Na}^{+}: 1 \mathrm{H}^{+}$ these results suggest an interaction between internal $\mathrm{H}^{+}$and a modifier site on the exchanger independent of the $\mathrm{H}^{+}$translocating site. The net effect of increasing internal $\mathrm{H}^{+}$is an allosteric increase in the rate of countertransport.

Another property of $\mathrm{Na}^{+}-\mathrm{H}^{+}$exchange is its reversible inhibition by the pyrazine diuretic amiloride (15). Studies of ${ }^{22} \mathrm{Na}^{+}$ flux in renal microvillus membrane vesicles indicate that amiloride competitively inhibits the external $\mathrm{Na}^{+}$site of the antiporter, with an inhibition constant $\left(K_{\mathrm{i}}\right)$ of $7-30 \mu \mathrm{M}(15)$; this is two to three orders of magnitude higher than the concentrations required for amiloride inhibition of $\mathrm{Na}^{+}$channels in tight epithelia such as the renal cortical collecting duct, the site of its diuretic action (16). Quinidine, another reversible inhibitor of the renal $\mathrm{Na}^{+}-\mathrm{H}^{+}$exchanger, not only increases the apparent $K_{\mathrm{m}}$ for $\mathrm{Na}^{+}$but decreases $\mathrm{V}_{\max }$ of $\mathrm{Na}^{+}$uptake indicating mixedtype inhibition. Based on kinetic considerations, it is likely that quinidine inhibits the exchanger through an interaction at an external binding site distinct from the $\mathrm{Na}^{+}$transport site (17).

Studies in isolated membrane vesicles have contributed to the elucidation of properties of the $\mathrm{Na}^{+}-\mathrm{H}^{+}$exchanger in wellcontrolled conditions and have characterized thermodynamic and kinetic properties of the transporter. It is noteworthy that properties of the $\mathrm{Na}^{+}-\mathrm{H}^{+}$exchanger observed in a variety of intact cells and tissues resemble closely those determined in renal vesicles. For example, in thymocyte suspensions electroneutral $\mathrm{Na}^{+}-\mathrm{H}^{+}$exchange in the plasma membrane has a stoichiometry of $1 \mathrm{Na}^{+}: 1 \mathrm{H}^{+}$, can mediate $\mathrm{Li}^{+}-\mathrm{H}^{+}$exchange, and is competitively inhibited by amiloride in micromolar concentrations (18). In these cells $\mathrm{Na}^{+}-\mathrm{H}^{+}$exchange is undetectable at cellular $\mathrm{pH}$ $>6.9$, even in the presence of favorable electrochemical driving forces, but can be activated by cellular acidification. This is consistent with regulation of the $\mathrm{Na}^{+}-\mathrm{H}^{+}$exchange rate by an internal $\mathrm{H}^{+}$modifier site, poised for maintenance of intracellular $\mathrm{pH}$.

In plasma membrane vesicles derived from human epidermoid carcinoma cells, $\mathrm{Na}^{+}-\mathrm{H}^{+}$exchange has affinity for $\mathrm{Li}^{+}$but not $\mathrm{K}^{+}$, is inhibited by amiloride, and is allosterically activated by acid intravesicular $\mathrm{pH}$ (19). Evidence in favor of an internal $\mathrm{H}^{+}$modifier site has also been demonstrated in chick skeletal muscle cells and human lymphocytes and fibroblasts (20). In general, amiloride inhibition is a characteristic of plasma membrane $\mathrm{Na}^{+}-\mathrm{H}^{+}$exchangers. However, in thymic lymphocytes an amiloride-insensitive cation exchanger mediating electroneutral $\mathrm{Na}^{+}-\mathrm{H}^{+}$exchange has been described (21). As noted for renal $\mathrm{Na}^{+}-\mathrm{H}^{+}$exchange, the transporter in cardiac sarcolemmal vesicles and dog red blood cells is also sensitive to quinidine (22-23).

Although the protein mediating $\mathrm{Na}^{+}-\mathrm{H}^{+}$exchange has yet to be isolated, preliminary characterization of chemical groups critical to the activity of the renal $\mathrm{Na}^{+}-\mathrm{H}^{+}$exchanger has been reported. First, there is evidence that the external $\mathrm{H}^{+}$binding site of the $\mathrm{Na}^{+}-\mathrm{H}^{+}$exchanger in renal microvillus membrane vesicles contains a histidine residue (24). The apparent $\mathrm{pK}$ for interaction of external $\mathrm{H}^{+}$with the exchanger is in the $\mathrm{pH}$ range of 7.3 to 7.5 , consistent with titration of an imidazolium group.
The histidine-reactive reagent diethylpyrocarbonate irreversibly reduces the $\mathrm{V}_{\max }$ for $\mathrm{Na}^{+}$uptake via $\mathrm{Na}^{+}-\mathrm{H}^{+}$exchange in the renal vesicles. The effects of amiloride, $\mathrm{Na}^{+}$and $\mathrm{pH}_{\mathrm{i}}$ on the process of inactivation by diethylpyrocarbonate suggest that the critical histidine residue is at the external transport site. In thymic lymphocytes diethylpyrocarbonate was similarly found to inhibit $\mathrm{Na}^{+}-\mathrm{H}^{+}$exchange (25). Second, there is evidence for the involvement of a critical carboxyl group in the functioning of the renal $\mathrm{Na}^{+}-\mathrm{H}^{+}$exchanger. Transport activity in renal microvillus membrane vesicles can be inactivated by the carboxyl-specific reagents ethoxy-carbonyl-ethoxy-dihydroquinoline (EEDQ) (26, 27) and $N, N^{1}$-dicyclohexylcarbodiimide (DCCD) (28). Amiloride protects against the irreversible interaction of EEDQ or DCCD with the exchanger $(27,28)$. Labeling vesicle proteins with $\left[{ }^{14} \mathrm{C}\right] \mathrm{DCCD}$ in the presence of amiloride prior to sodium dodecyl sulfate-polyacrylamide gel electrophoresis results in a marked reduction in a $100-\mathrm{kD}$ polypeptide, which may be a component of the $\mathrm{Na}^{+}-\mathrm{H}^{+}$exchange protein (28). Third, an internal sulfhydryl (SH) group is involved in exchanger activity. In lymphocytes, SH-reactive agents that permeate the cells give inhibition of the exchanger, whereas impermeant analogues are without effect (25). These data suggest that an internal SH group has importance in determining the transport rate of the carrier and that SH-alkylating agents may have usefulness in the characterization of the transport protein.

Roles of $\mathrm{Na}^{+}-\mathrm{H}^{+}$exchange in cell function. It is now clear that diverse types of cells utilize a plasma membrane $\mathrm{Na}^{+}-\mathrm{H}^{+}$ antiporter to maintain $\mathrm{pH}_{\mathrm{i}}$. It has been found in neuronal cells, skeletal, cardiac, and vascular smooth muscle, endothelial cells, fibroblasts, lymphocytes, and in numerous tumor cells in culture (29-39). Because the investigators of these cell types have been interested in the relationship between the ionic milieu $\left(\mathrm{pH}, \mathrm{Na}^{+}\right.$, $\mathrm{K}^{+}$) and metabolic function, much has been learned about the importance of $\mathrm{Na}^{+}-\mathrm{H}^{+}$exchange in the processes of hormone action, cell growth regulation, and cell differentiation (Table I).

The interaction between $\mathrm{Na}^{+}-\mathrm{H}^{+}$exchange and cell function was first examined in fertilized sea urchin eggs (40). Cytoplasmic alkalinization, a requirement for the development of the fertilized egg, is dependent on external $\mathrm{Na}^{+}$and inhibitable by amiloride. Furthermore a peptide (speract) associated with the egg stimulates sperm motility and respiration by activating $\mathrm{Na}^{+}-\mathrm{H}^{+}$exchange in the sperm cell (41). Similarly, in frog sartorius muscle an effect of insulin to stimulate glycolysis is related to the hormone's ability to alkalinize the cytoplasm by activating $\mathrm{Na}^{+}-\mathrm{H}^{+}$exchange in the plasma membrane (42).

Perhaps the most extensively studied role of $\mathrm{Na}^{+}-\mathrm{H}^{+}$exchange as a signal for biochemical events is its relationship to the process of cell growth. For example, cultured fibroblasts deprived of serum enter a quiescent phase and can be stimulated to proliferate by readdition of serum or purified growth factors (43-48). It was demonstrated that the growth phase is associated with an increase in $\mathrm{Na}^{+}-\mathrm{K}^{+}$-ATPase activity. The time course of ionic fluxes indicates that the initial event in pump stimulation is the entry of $\mathrm{Na}^{+}$from the extracellular fluid $(44,48)$. The increased cell $\mathrm{Na}^{+}$then stimulates $\mathrm{Na}^{+}-\mathrm{K}^{+}$pump activity, which increases cell $\mathrm{K}^{+}$. Elevated cell $\mathrm{Na}^{+}$and $\mathrm{K}^{+}$have each been considered important in the process of DNA and protein synthesis. Growth does not occur when cells are placed in low $\mathrm{Na}^{+}$ media (49). It was subsequently demonstrated that the $\mathrm{Na}^{+}$influx is via an electroneutral and amiloride-sensitive $\mathrm{Na}^{+}-\mathrm{H}^{+}$exchanger $(43,45-47)$. In addition to increasing cell $\mathrm{Na}^{+}$, there are noted early elevations in intracellular $\mathrm{pH}$ as cells begin to grow. The time course of intracellular $\mathrm{pH}$ change and DNA synthesis measured by $\left[{ }^{3} \mathrm{H}\right]$ thymidine incorporation is most 
Table I. Examples of Tissues in Which External Stimuli Regulate $\mathrm{Na}^{+}-\mathrm{H}^{+}$Exchange

\begin{tabular}{|c|c|}
\hline Tissue & Stimulus \\
\hline \multicolumn{2}{|l|}{ Increased $\mathrm{Na}^{+}-\mathrm{H}^{+}$Exchange } \\
\hline Sea urchin egg & Fertilization (40) \\
\hline Sea urchin spermatozoa & Sea urchin egg, speract (41) \\
\hline Fibroblasts & $\begin{array}{l}\text { Serum (43-48), thrombin (47), insulin } \\
\text { (59), vasopressin }(63) \text {, bradykinin } \\
\text { (62), EGF }(39,55,59) \text {, PDGF }(60) \text {, } \\
\text { phorbol esters }(83)\end{array}$ \\
\hline Vascular smooth muscle & $\begin{array}{l}\text { Serum, PDGF, } \mathrm{Ca}^{2+} \text { inophores (31), } \\
\text { angiotensin (61) }\end{array}$ \\
\hline Frog skeletal muscle & Insulin (42) \\
\hline Cardiac muscle & Intracellular acid load (105) \\
\hline Neurons & Intracellular acid load (106) \\
\hline Red blood cells & $\begin{array}{l}\text { Osmotic shrinkage (6), catecholamines } \\
\quad(107)\end{array}$ \\
\hline Neutrophils & $\begin{array}{l}\text { Chemotactic factors }(65,66), \text { phorbol } \\
\text { esters }(84)\end{array}$ \\
\hline Lymphocytes & $\begin{array}{l}\text { Concanavalin A (34), osmotic shrink- } \\
\text { age (67), phorbol esters (85) }\end{array}$ \\
\hline Platelets & Thrombin (64) \\
\hline \multicolumn{2}{|l|}{ Tumor cells } \\
\hline Epidermoid carcinoma & EGF $(39,57)$ \\
\hline Glioma & Bradykinin (108) \\
\hline Leukemia & Phorbol esters (38) \\
\hline Neuroblastoma & Serum (109), phorbol esters (83) \\
\hline Pheochromocytoma & EGF (58) \\
\hline Hepatocytes & EGF (56) \\
\hline Gallbladder epithelia & Osmotic shrinkage (68) \\
\hline Renal proximal tubule & $\begin{array}{l}\text { Metabolic acidosis }(94-96), \mathrm{K}^{+} \text {deple- } \\
\text { tion (97), partial renal ablation }(98), \\
\text { glucocorticoids (99), thyroid hor- } \\
\text { mone (100), renal failure (110), } \\
\text { parathyroidectomy (94), diabetes } \\
\text { mellitus (111). }\end{array}$ \\
\hline \multicolumn{2}{|c|}{ Decreased $\mathrm{Na}^{+}-\mathrm{H}^{+}$Exchange } \\
\hline Gall bladder epithelia & cAMP $(90)$ \\
\hline Renal proximal tubule & $\begin{array}{l}\text { Parathyroid hormone, cAMP ( } 91 \text {, } \\
\text { 112). }\end{array}$ \\
\hline
\end{tabular}

consistent with a link between $\mathrm{pH}_{\mathrm{i}}$ and the growth response (47). Additional evidence favoring an important regulatory role of $\mathrm{Na}^{+}-\mathrm{H}^{+}$exchange on $\mathrm{pH}_{\mathrm{i}}$ in cell growth comes from studies of mutant fibroblasts lacking $\mathrm{Na}^{+}-\mathrm{H}^{+}$exchange. These cells do not grow in neutral or acidic media. However, if extracellular $\mathrm{pH}$ is raised so that intracellular $\mathrm{pH}$ becomes more alkaline, the mutant cells lacking $\mathrm{Na}^{+}-\mathrm{H}^{+}$exchange can grow (50). The role of the $\mathrm{Na}^{+}-\mathrm{H}^{+}$exchanger in the response to mitogenic factors thus is to elevate $\mathrm{pH}_{\mathrm{i}}$ to a level permissive for cell growth; cell uptake of $\mathrm{Na}^{+}$or $\mathrm{K}^{+}$is apparently not required for cell growth in this case. It is interesting that the mutant fibroblasts lacking $\mathrm{Na}^{+}-\mathrm{H}^{+}$ exchange can grow in neutral or acidic media if $\mathrm{HCO}_{3}^{-}$is present, in which case intracellular $\mathrm{pH}$ is regulated by $\mathrm{Na}^{+}$-dependent $\mathrm{Cl}^{-}-\mathrm{HCO}_{3}^{-}$exchange in these cells (51).

The use of amiloride inhibition of cell growth to prove the importance of $\mathrm{Na}^{+}-\mathrm{H}^{+}$exchange has been criticized because of the ability of the drug to directly inhibit protein synthesis (52). More potent amiloride analogues can be used in lower concentrations, however, that do not interfere with metabolic reactions (53); these agents have confirmed the importance of $\mathrm{Na}^{+}-\mathrm{H}^{+}$ exchange to the process of cell growth. Fibroblasts either lacking
$\mathrm{Na}^{+}-\mathrm{H}^{+}$exchange $(50)$ or treated with inhibitory concentrations of amlioride (54) may still initiate DNA synthesis in response to serum or growth factors if exposed to $\mathrm{CO}_{2}-\mathrm{HCO}_{3}^{-}$media. In these cells, $\mathrm{Na}^{+}-\mathrm{H}^{+}$exchange thus may not be a requirement for growth; other $\mathrm{pH}_{\mathrm{i}}$ regulating mechanisms may overcome the loss of antiporter activity.

In view of the effect of serum on $\mathrm{Na}^{+}-\mathrm{H}^{+}$exchange and cell growth, the effects of various purified growth factors, alone or in combination, on cell $\mathrm{Na}^{+}-\mathrm{H}^{+}$antiport have been examined. For example, the polypeptide epidermal growth factor (EGF) stimulates amiloride-sensitive $\mathrm{Na}^{+}$uptake and causes intracellular alkalinization prior to its known effect to increase DNA synthesis in fibroblasts, hepatocytes, human epidermoid carcinoma cells, and pheochromocytoma cells $(39,55-58)$. A study in human fibroblasts suggests that EGF alters the internal $\mathrm{H}^{+}$ modifier site of the $\mathrm{Na}^{+}-\mathrm{H}^{+}$exchanger, thereby making the antiporter more sensitive to $\mathrm{pH}_{\mathrm{i}}(59)$. Platelet-derived growth factor (PDGF) has been shown to cause an increase in $\mathrm{pH}_{\mathrm{i}}$ of cultured fibroblasts and vascular smooth muscle cells, an effect requiring external $\mathrm{Na}^{+}$and inhibitable by amiloride $(31,60)$. Other mitogenic peptides known to stimulate $\mathrm{Na}^{+}-\mathrm{H}^{+}$exchange include angiotensin in aortic smooth muscle cells, an effect blocked by saralasin and amiloride (61), lys-bradykinin in human fibroblasts (62), and vasopressin (63). Insulin has been observed to increase $\mathrm{Na}^{+}-\mathrm{H}^{+}$countertransport in skeletal muscles cells (42); in fibroblasts it has synergistic actions with EGF suggesting a different mechanism of action (59). Thrombin activation of platelets is related to its function to increase $\mathrm{Na}^{+}$uptake by the platelet (64), and this protein exerts a mitogenic effect and enhances $\mathrm{Na}^{+}-\mathrm{H}^{+}$exchange in cultured fibroblasts (47). Finally, chemotactic factors such as arachidonic acid and leukotriene $B_{4}$ stimulate amiloride-sensitive $\mathrm{Na}^{+}$influx in neutrophils (65). Also in neutrophils, the stimulation of the respiratory burst by $f$-MetLeu-Phe is related to intracellular alkalinization due to activation of $\mathrm{Na}^{+}-\mathrm{H}^{+}$exchange $(65,66)$.

It is clear from these examples that stimulation of plasma membrane $\mathrm{Na}^{+}-\mathrm{H}^{+}$exchange is an important intermediate step between extracellular first messengers and biological responses, particularly cell growth. It should be noted, however, that mitogenic factors also have effects that are clearly independent of $\mathrm{Na}^{+}-\mathrm{H}^{+}$exchange or $\mathrm{pH}_{\mathrm{i}}$. In fact, certain growth factors stimulate $\mathrm{Na}^{+}$uptake without having mitogenic effects, particularly in tumor cells (39). Furthermore, growth factor stimulation of the cell may induce a series of biochemical changes despite inhibition of the $\mathrm{Na}^{+}-\mathrm{H}^{+}$exchanger (39). It is also possible that changes in cell $\mathrm{Na}^{+}$and $\mathrm{K}^{+}$content as well as $\mathrm{pH}_{\mathrm{i}}$ are important to cell function in some cases. Also, other transport processes such as $\mathrm{Cl}^{-}-\mathrm{HCO}_{3}^{-}$exchange may contribute to cellular $\mathrm{pH}$ regulation.

$\mathrm{Na}^{+}-\mathrm{H}^{+}$exchangers present in the plasma membranes of red blood cells, lymphocytes, and gallbladder epithelia play an important role in cell volume regulation $(6,67,68)$. Osmotic shrinking of hypotonically pretreated lymphocytes is followed by a reswelling associated with an increase in cell $\mathrm{Na}^{+}$content and intracellular alkalinization (67). This process is dependent on extracellular $\mathrm{Na}^{+}$, is electroneutral and is inhibited by amiloride, consistent with $\mathrm{Na}^{+}-\mathrm{H}^{+}$countertransport. Recovery of cell volume after osmotic shrinkage in amphiuma red cells (6) and Necturus gallbladder (68) is thought to result from parallel activation of $\mathrm{Na}^{+}-\mathrm{H}^{+}$and $\mathrm{Cl}^{-}-\mathrm{HCO}_{3}^{-}$exchangers in the cell membranes.

$\mathrm{Na}^{+}-\mathrm{H}^{+}$exchange is a major transport pathway involved in the transepithelial transport of $\mathrm{Na}^{+}, \mathrm{HCO}_{3}^{-}$, and $\mathrm{Cl}^{-}$in diverse epithelia. For example, the mammalian proximal tubule reabsorbs $80-90 \%$ of $\mathrm{HCO}_{3}^{-}$filtered at the glomerulus. The process 
responsible for acidification in the proximal nephron is secretion of $\mathrm{H}^{+}$from cell to lumen (69). $\mathrm{H}^{+}$secretion has been shown to be largely dependent on luminal $\mathrm{Na}^{+}$and to be inhibited by amiloride. These findings are consistent with an important role of luminal $\mathrm{Na}^{+}-\mathrm{H}^{+}$exchange $(70,71)$. Since $\mathrm{HCO}_{3}^{-}$is one of the principal solutes reabsorbed with $\mathrm{Na}^{+}$in the proximal convoluted tubule, the $\mathrm{Na}^{+}-\mathrm{H}^{+}$antiporter also makes an important contribution to net $\mathrm{Na}^{+}$reabsorption in this segment. Acid secretion accomplished by luminal membrane $\mathrm{Na}^{+}-\mathrm{H}^{+}$exchangers also contributes to the process of net $\mathrm{HCO}_{3}^{-}$absorption in epithelial cells of the renal thick ascending limb of Henle $(72,73)$, and small intestine (7). Where present on the basolateral membrane, as in cells of the exocrine pancreas $(74,75)$, choroid plexus $(76)$, and cornea (77), $\mathrm{Na}^{+}-\mathrm{H}^{+}$exchange represents a mechanism for uphill entry of $\mathrm{HCO}_{3}^{-}$into cells from the extracellular fluid and is therefore important for net $\mathrm{HCO}_{3}^{-}$secretion. In gallbladder (8), small intestine (77a), renal cortical thick ascending limb of Henle (72), and amphibian proximal tubule (77b) the parallel operation of $\mathrm{Na}^{+}-\mathrm{H}^{+}$and $\mathrm{Cl}^{-}-\mathrm{HCO}_{3}^{-}$exchangers on the luminal membrane contributes to net $\mathrm{NaCl}$ absorption. In the mammalian proximal tubule electroneutral $\mathrm{NaCl}$ absorption may in part occur by parallel processes of $\mathrm{Na}^{+}-\mathrm{H}^{+}$exchange and $\mathrm{Cl}^{-}$formate exchange across the luminal membrane (78). By this mechanism, $\mathrm{H}^{+}$secretion acidifies the luminal fluid resulting in an increase in formic acid transport into the cell by nonionic diffusion. As cellular formate concentrations increase, $\mathrm{Cl}^{-}$influx coupled to formate efflux ( $\mathrm{Cl}^{-}$-formate exchange) can take place. The recycling of formic acid back into the cell may enable the relatively small physiologic concentrations of this short-chain fatty acid to stimulate absorption of larger amounts of $\mathrm{Cl}^{-}$.

Mechanisms of regulation of $\mathrm{Na}^{+}-\mathrm{H}^{+}$exchange. As a consequence of the experimental evidence assigning importance to monovalent ionic fluxes as a signal for biochemical events, recent investigations have attempted to clarify the molecular mechanisms involved in the regulation of $\mathrm{Na}^{+}-\mathrm{H}^{+}$exchange activity. Of particular interest is the observation that several mitogens and hormones induce phosphorylation of specific cell proteins simultaneous to their effects on ion transport (79). Several lines of evidence suggest an important role of membrane phospholipids in initiating the response of $\mathrm{Na}^{+}-\mathrm{H}^{+}$exchange to mitogenic stimulation (80). Several potent mitogens known to increase antiporter activity (e.g., EGF, PDGF, angiotensin, and vasopressin) are also known to mediate hydrolysis of phosphatidylinositol to the products diacylglycerol and inositol trisphosphate $(80,81)$. Diacylglycerol and cytosolic $\mathrm{Ca}^{2+}$ synergistically activate phospholipid-dependent $C$ kinase (82). Since synthetic diacylglycerols and tumor-promoting phorbol esters, known activators of protein $\mathrm{C}$ kinase, also stimulate $\mathrm{Na}^{+}-\mathrm{H}^{+}$exchange in human fibroblasts (83), neutrophils (84), lymphocytes (85), and human leukemic cells (86), this biochemical pathway has been considered an important regulator of the antiporter in these cells. However, it is not known whether the transport protein itself is a substrate for C-kinase phosphorylation. In rat thymic lymphocytes, tumor-promoting phorbol esters and other C-kinase activators alter the sensitivity of $\mathrm{Na}^{+}-\mathrm{H}^{+}$exchange to intracellular pH consistent with an effect on the internal $\mathrm{H}^{+}$modifier site (85). In this system, phorbol ester addition results in increased $\mathrm{Na}^{+}$influx, cell swelling, and secondary increases in $\mathrm{Na}^{+}-\mathrm{K}^{+}$ pump activity. Since the stimulation of $\mathrm{Na}^{+}-\mathrm{H}^{+}$exchange by phorbol esters in the neutrophil is also observed in degranulated and enucleated cells (cytoplasts), the effect is probably independent of recruitment of $\mathrm{Na}^{+}-\mathrm{H}^{+}$exchangers by exocytosis of intracellular vesicles (84).
Another mechanism proposed for regulation of $\mathrm{Na}^{+}-\mathrm{H}^{+}$exchange is activation of calmodulin-dependent protein kinases by cytosolic $\mathrm{Ca}^{2+}$. It is thought that inositol trisphosphate can mediate release of $\mathrm{Ca}^{2+}$ from intracellular stores resulting in a transient increase in cytosolic $\mathrm{Ca}^{2+}$ concentration. Stimulation of $\mathrm{Na}^{+}-\mathrm{H}^{+}$exchange by growth factors in Swiss 3T3 cells and vascular smooth muscle is blocked by calcium antagonists and nonspecific inhibitors of calmodulin (trifluoroperazine, chlorpromazine, and imipramine), suggesting importance for this pathway (87). Although an increase in cytosolic $\mathrm{Ca}^{2+}$ has been noted after mitogenic stimulation of fibroblasts (88) and metabolic activation of the fertilized sea urchin egg (89), others have not observed changes in cytosolic $\mathrm{Ca}^{2+}$ during growth (83) or have dissociated increases in $\mathrm{Ca}^{2+}$ concentration from antiporter activation (39).

A third mechanism of regulation of $\mathrm{Na}^{+}-\mathrm{H}^{+}$exchange involves cAMP-dependent pathways. In gallbladder epithelia, cAMP analogues inhibit apical $\mathrm{Na}^{+}$entry via $\mathrm{Na}^{+}-\mathrm{H}^{+}$exchange (90). This is associated with an increase in $\mathrm{Cl}^{-}$permeability of the luminal membrane, thereby increasing $\mathrm{Cl}^{-}$backleak into the lumen and decreasing net $\mathrm{NaCl}$ and water absorption. In the renal proximal tubule, parathyroid hormone and cAMP analogues decrease activity of the luminal membrane $\mathrm{Na}^{+}-\mathrm{H}^{+}$exchanger (91), consistent with known effects of the hormone to decrease proximal acidification.

EGF, known to have plasma membrane receptors on many cell types, is closely linked to a tyrosine specific protein kinase (92). Since EGF is a known activator of $\mathrm{Na}^{+}-\mathrm{H}^{+}$exchange it remains possible that function of a tyrosine kinase is important to regulation of the antiporter. Addition of EGF to target cells stimulates this kinase activity resulting in phosphorylation of several membrane proteins including the EGF receptor itself (92). Phosphorylation of tyrosine residues is thought to play an important role in the physiological effects of EGF. PDGF also induces tyrosine phosphorylation in Swiss 3T3 cells within minutes of exposure (93). Both EGF and PDGF phosphorylate proteins of similar molecular weight suggesting that these proteins are involved in the common physiological effects of the peptides (93). The importance of tyrosine kinase activity to cell proliferation has also been implied by the observation that transforming proteins of retroviruses and EGF induce phosphorylation of identical proteins (92). Although the physiologic functions of many of the phosphoproteins formed after addition to cells of hormones and growth factors are presently unknown, it remains possible that the protein mediating $\mathrm{Na}^{+}-\mathrm{H}^{+}$exchange, or other transport regulating proteins, are directly modified. The role of various protein kinases in regulating $\mathrm{Na}^{+}-\mathrm{H}^{+}$exchange activity has been recently reviewed (93a).

Role of the $\mathrm{Na}^{+}-\mathrm{H}^{+}$exchanger in pathophysiologic states. The presence of $\mathrm{Na}^{+}-\mathrm{H}^{+}$exchangers in a variety of tumor cells, and the activating properties of mitogenic growth factors and tumor-promoting phorbol esters on the antiporter suggest that this transport process may have important functions in the control of tumor growth. It is also reasonable to expect that activation of this transport system may be involved in nonmalignant forms of tissue and organ development, growth, or hypertrophy.

The study of the renal $\mathrm{Na}^{+}-\mathrm{H}^{+}$exchanger in animal models of acid-base and electrolyte disorders has provided insight into the long-term regulation of the antiporter in the proximal tubule. For example, in metabolic acidosis (94-96) and chronic dietary $\mathrm{K}^{+}$depletion (97), increases in $\mathrm{Na}^{+}-\mathrm{H}^{+}$exchange activity in microvillus membrane vesicles correlate with the finding of increased proximal tubule $\mathrm{H}^{+}$secretion in these conditions. In 
chronic states produced by contralateral nephrectomy, highprotein diets (98), and glucocorticoid and thyroid hormone treatment $(99,100)$, increases in $\mathrm{Na}^{+}-\mathrm{H}^{+}$exchange correlate with increases in single nephron glomerular filtration rate and proximal $\mathrm{Na}^{+}$and $\mathrm{HCO}_{3}^{-}$reabsorption. Interestingly, each of these adaptations is associated with renal growth and biochemical evidence for hypertrophy and hyperplasia. As discussed in the previous section, $\mathrm{Na}^{+}-\mathrm{H}^{+}$exchange in nonrenal cells plays an important role in the process of cell growth. It is of particular interest that increased DNA synthesis in a cultured kidney cell line exposed to low extracellular $\mathrm{K}^{+}$concentrations is associated with increased cell $\mathrm{Na}^{+}$concentrations (101). These data suggest that an increased $\mathrm{Na}^{+}$uptake mechanism induced by $\mathrm{K}^{+}$depletion may precede cell proliferation. This may explain the enhanced $\mathrm{Na}^{+}-\mathrm{H}^{+}$exchange activity observed in renal vesicles from $\mathrm{K}^{+}$depleted animals.

A role for defective jejunal $\mathrm{Na}^{+}-\mathrm{H}^{+}$exchange in the development of congenital secretory diarrhea has been proposed (102). This condition is associated with metabolic acidosis due to increased content of $\mathrm{HCO}_{3}^{-}$in the stool. Membrane vesicles derived from tissue obtained by jejunal biopsy in a patient with this disorder demonstrated decreased $\mathrm{Na}^{+}-\mathrm{H}^{+}$exchange suggesting that a specific congenital membrane defect may be responsible for the diarrhea.

Essential hypertension in humans has been correlated with abnormalities in cellular transport of cations. For example, patients with essential hypertension and their family members have increased $\mathrm{Na}^{+}-\mathrm{Na}^{+}$and $\mathrm{Na}^{+}-\mathrm{Li}^{+}$countertransport in circulating blood cells (103). If cation countertransport in blood cells were a marker for activity of $\mathrm{Na}^{+}-\mathrm{H}^{+}$exchange in the proximal tubule or loop of Henle, increased activity would be associated with a primary increase in $\mathrm{NaCl}$ reabsorption in some forms of human hypertension. Consistent with this hypothesis is the observation that increased red blood cell $\mathrm{Na}^{+}-\mathrm{Li}^{+}$countertransport in hypertensives is correlated with increased proximal tubule $\mathrm{Na}^{+}$ reabsorption (104). Since angiotensin is a known stimulus to $\mathrm{Na}^{+}-\mathrm{H}^{+}$exchange in vascular smooth muscle $(61)$, it is also possible that a hormone-induced increase in cell $\mathrm{Na}^{+}$content or $\mathrm{pH}_{\mathrm{i}}$ may result in increased vascular tone and/or vascular hyperplasia in hypertensive states. The role of cation transporters in the expression or pathogenesis of human hypertension will require further investigation.

\section{Conclusion}

In summary, plasma membrane $\mathrm{Na}^{+}-\mathrm{H}^{+}$exchangers have been identified in a wide variety of animal cells. The common properties of the exchanger include $1: 1$ electroneutral $\mathrm{Na}^{+}-\mathrm{H}^{+}$countertransport, affinity for $\mathrm{Li}^{+}$in addition to $\mathrm{Na}^{+}$and $\mathrm{H}^{+}$, sensitivity to the inhibitor amiloride, and an internal $\mathrm{H}^{+}$modifier site that functions to allosterically increase the antiporter rate as a function of decreasing intracellular $\mathrm{pH}$. The carrier serves a major role in intracellular $\mathrm{pH}$ regulation and thereby mediates $\mathrm{pH}$ dependent metabolic responses such as those involved in cell growth. $\mathrm{Na}^{+}-\mathrm{H}^{+}$exchange affects cell $\mathrm{Na}^{+}$content and thus contributes to the process of cell volume regulation. Several hormones alter the activity of the exchanger and may therefore influence biochemical events by changing cellular ionic content or $\mathrm{pH}_{\mathrm{i}}$. Membrane phosphorylation mediated by a spectrum of protein kinases has been implicated in the regulation of antiporter activity. Greater understanding of the mechanisms for regulation of the $\mathrm{Na}^{+}-\mathrm{H}^{+}$exchanger will undoubtedly result from current efforts directed at identifying the transport protein and cloning its gene. Current work is also directed at evaluating the role of this transport system in a variety of pathophysiologic states, such as malignant and nonmalignant growth, hypertension, and disorders of acid-base and electrolyte homeostasis.

\section{References}

1. Busa, W. B., and R. Nuccitelli. 1984. Am. J. Physiol. 240:R409438.

2. Ives, H. E., and F. C. Rector, Jr. 1984. J. Clin. Invest. 73:285290.

3. Thomas, R. C. 1977. J. Physiol. 273:317-338.

4. Boron, W. F., and J. M. Russell. 1983. J. Gen. Physiol. 81:373399.

5. Aronson, P. S. 1981. Am. J. Physiol. 240:F1-11.

6. Cala, P. M. 1980. J. Gen. Physiol. 76:683-708.

7. Murer, H., U. Hopfer, and R. Kinne. 1976. Biochem. J. 154:597604.

8. Weinman, S. A., and L. Reuss. 1984. J. Gen. Physiol. 83:57-74.

9. Aronson, P. S. 1983. Am. J. Physiol. 245:F647-659.

10. Kinsella, J. L., and P. S. Aronson. 1980. Am. J. Physiol. 238: F461-469.

11. Kinsella, J. L., and P. S. Aronson. 1982. Biochem. Biophys. Acta. 689:161-164.

12. Kinsella, J. L., and P. S. Aronson. 1981. Am. J. Physiol. 241: C220-C226.

13. Aronson, P. S., M. A. Suhm, and J. Nee. 1983. J. Biol. Chem. 258:6767-6771.

14. Aronson, P. S., J. Nee, and M. A. Suhm. 1982. Nature (Lond.). 299:161-163.

15. Kinsella, J. L., and P. S. Aronson. 1981. Am. J. Physiol. 241: F374-F379.

16. Benos, D. J. 1982. Am. J. Physiol. 242:C131-C145.

17. Mahnensmith, R. L., and P. S. Aronson. 1985. J. Biol. Chem. 260:12586-12592.

18. Grinstein, S., S. Cohen, and A. Rothstein. 1984. J. Gen. Physiol. 83:341-369.

19. Mancuso, D., and L. Glaser. 1985. J. Cell. Physiol. 123:297304.

20. Moolenaar, W. H., L. G. Tertoolen, and S. W. de Laat. 1984. J. Biol. Chem. 259:7563-7569.

21. Grinstein, S., J. D. Goetz, and A. Rothstein. 1984. J. Gen. Physiol. 84:565-584.

22. Seiler, S. H., E. J. Cragoe, Jr., and L. R. Jones. 1985. J. Biol. Chem. 260:4869-4876.

23. Parker, J. C. 1983. Am. J. Physiol. 244:C324-C330.

24. Grillo, F. G., and P. S. Aronson. 1986. J. Biochem. 261:11201125.

25. Grinstein, S., S. Cohen, and A. Rothstein. 1985. Biochim. Biophys. Acta. 812:213-222.

26. Burnham, C., C. Munzesheimer, E. Rabon, and G. Sachs. 1982. Biochim. Biophys. Acta. 685:260-272.

27. Rocco, V. K., D. G. Yick, V. J. Yee, E. J. Cragoe, Jr., and D. G. Warnock. 1986. Kidney Int. 29:405a.

28. Aronson, P. S., and P. Igarashi. 1986. Curr. Topics Membr. Transport 26:57-75.

29. Vigne, P., C. Frelin, and M. Lazdunski. 1982. J. Biol. Chem. 257:9394-9400.

30. Piwnica-Worms, D., and M. Lieberman. 1983. Am. J. Physiol. 244:C422-C428.

31. Owen, N. E. 1984. Am. J. Physiol. 247:C501-C505.

32. Betz, A. L. 1983. J. Neurochem. 41:1150-1157.

33. Schuldiner, S., and E. Rozengurt. 1982. Proc. Natl. Acad. Sci. USA. 79:7778-7782

34. Gerson, D. F., and H. Kiefer. 1983. J. Cell. Physiol. 114:132136.

35. Moolenaar, W. H., J. Boonstra, P. T. Van der Saag, and S. W. de Laat. 1981. J. Biol. Chem. 256:12883-12887.

36. Moolenaar, W. H., C. L. Mummery, P. T. Van der Saag, and S. W. de Laat. 1981. Cell. 23:789-798. 
37. Rozengurt, E. 1982. J. Cell. Physiol. 112:243-250.

38. Besterman, J. M., and P. Cuatrecasas. 1984. J. Cell Biol. 99:340343.

39. Rothenberg, P., L. Glaser, P. Schlesinger, and D. Cassel. 1983. J. Biol. Chem. 258:12644-12653.

40. Johnson, J. D., D. Epel, and M. Paul. 1976. Nature (Lond.). 262: 661-664.

41. Hansbrough, J. R., and D. C. Garbers. 1981. J. Biol. Chem. 256: 2235-2241.

42. Moore, R. D. 1979. Biochem. Biophys. Res. Commun. 91:900904.

43. Schuldiner, S., and E. Rozengurt. 1982. Proc. Natl. Acad. Sci. USA. 79:7778-7782.

44. Smith, J. B., and E. Rozengurt. 1978. Proc. Natl. Acad. Sci. USA. 75:5560-5564. 3508 .

45. Paris, S., and J. Pouyssegur. 1983. J. Biol. Chem. 258:3503-

46. Frelin, C., P. Vigne, and M. Lazdunski. 1983. J. Biol. Chem. 258:6272-6278.

47. L'Allemain, G., S. Paris, and J. Pouyssegur. 1984. J. Biol. Chem. 259:5809-5815.

48. Rozengurt, E., T. D. Gelehirter, A. Legg, and P. Pettican. 1981. Cell. 23(3):781-788. 1089.

49. Burns, C. P., and E. Rozengurt. 1984. J. Cell Biol. 98:1082-

50. Pouyssegur, J., C. Ardet, A. Franchi, G. L'Allemain, and S. Paris. 1984. Proc. Natl. Acad. Sci. USA. 81:4833-4837.

51. L'Allemain, G., S. Paris, and J. Pouyssegur. 1984. J. Biol. Chem. 260:4877-4883.

52. Leffert, H. L., K. S. Koch, M. Fehlman, W. Heiser, P. J. Lad and H. Skelly. 1982. Biochem. Biophys. Res. Commun. 108:738-745.

53. Besterman, J. M., W. S. May, H. Levine III, E. J. Cragoe, Jr., and P. Cuatrecasas. 1985. J. Biol. Chem. 260:1155-1159.

54. Besterman, J. M., S. J. Tyrey, E. J. Cragoe, Jr., and P. Cuatrecasas. 1984. Proc. Natl. Acad. Sci. USA. 81:6762-6766.

55. Moolenaar, W. H., Y. Yarden, S. W. de Laat, and J. Schlessinger. 1982. J. Biol. Chem. 257:8502-8506.

56. Koch, K. S., and H. L. Leffert. 1979. Cell. 18:153-163.

57. Rothenberg, P., L. Glaser, P. Schlesinger, and D. Cassel. 1983. J. Biol. Chem. 258:4883-4889.

58. Boonstra, J., W. H. Moolenaar, P. H. Harrison, P. Moed, P. T. Van der Saag, and S. W. de Laat. 1983. J. Cell Biol. 97:92-96.

59. Moolenaar, W. H., R. Y. Tsien, P. T. Van der Saag, and S. W. deLaat. 1983. Nature (Lond.). 304:645-648.

60. Cassel, D., P. Rothenberg, Y. X. Zhuang, T. F. Deuel, and L. Glaser. 1983. Proc. Natl. Acad. Sci. USA. 80:6224-6228.

61. Smith, J. B., and T. A. Brock. 1983. J. Cell Physiol. 114:284290.

62. Owen, N. E., and M. L. Villereal. 1983. Cell. 32:979-985.

63. Mendoza, S. A., N. M., Wigglesworth, and E. Rozengurt. 1980.

J. Cell. Physiol. 105:153-162.

64. Greenberg-Sepersky, S. M., and E. R. Simons. 1984. J. Biol. Chem. 259:1502-1508.

65. Molski, T. F. P., P. H. Naccache, P. Borgeat, and R. I. Sha'afi.

1981. Biochem. Biophys. Res. Commun. 103:227-232.

66. Simchowitz, L. 1985. J. Clin. Invest. 76:1079-1089.

67. Grinstein, S., C. A. Clark, and A. Rothstein. 1983. J. Gen. Physiol. 82:619-638.

68. Ericson, A. C., and K. R. Spring. 1982. Am. J. Physiol. 243: C146-C150.

69. Dubose, T. D. Jr., L. R. Pucacco, and N. W. Cortes. 1981. Am. J. Physiol. 240:F138-F146.

70. Chantrelle, B., M. G. Cogan, and F. C. Rector, Jr. 1982. Pfluegers Arch. Eur. J. Physiol. 395:186-189.

71. McKinney, T. D., and M. B. Burg. 1977. Kidney Int. 12:1-8.

72. Friedman, P. A., and T. E. Andreoli. 1982. J. Gen. Physiol. 80: 683-712.

73. Good, D. W. 1985. Am. J. Physiol. 248:F821-F829.

74. Swanson, C. H., and A. K. Soloman. 1975. J. Gen. Physiol. 65: 22-45.
75. Hellnessen, W., A. L. Christian, H. Fasold, and I. Schulz. 1985.

Am. J. Physiol. 249:G125-136.

76. Wright, E. M. 1977. Biochim. Biophys. Acta. 468:486-489.

77. Jentsch, T. J., T. R. Stahlknecht, H. Hollwede, D. G. Fischer,

S. K. Keller, and M. Wiederholt. 1985. J. Biol. Chem. 260:795-801.

77a. Knickelbein, R., P. S. Aronson, C. M. Schron, J. Seifter, and

J. W. Dobbins. 1985. Am. J. Physiol. 249:G236-G245.

77b. Seifter, J. L., and P. S. Aronson. 1984. Am. J. Physiol. 247: F888-F895.

78. Karniski, L. P., and P. S. Aronson. 1985. Proc. Natl. Acad. Sci. USA. 82:6362-6365.

79. Pouyssegur, J., J. C. Chambard, A. Franchi, S. Paris, and E. Van Obberghen-Schilling. 1982. Proc. Natl. Acad. Sci. USA. 79:3935-3939. 80. Macara, I. G. 1985. Am. J. Physiol. 248:C3-C11.

81. Garrison, J. C., D. E. Johnsen, and C. P. Campanile. 1984. J. Biol. Chem. 259:3283-3292.

82. Nishizuka, Y. 1984. Science (Wash. DC). 225:1365-1370.

83. Moolenaar, W. H., L. G. J. Tertoolen, and S. W. de Laat. 1984. Nature (Lond.). 312:371-374

84. Grinstein, S., B. Elder, and W. Furuya. 1985. Am. J. Physiol. 248:C379-C386.

85. Grinstein, S., S. Cohen, J. D. Goetz, A. Rothstein, and F. W. Gelfand. 1985. Proc. Natl. Acad. Sci. USA. 82:1429-1433.

86. Rosoff, P. M., L. F. Stein, and L. C. Cantley. 1984. J. Biol. Chem. 259:7056-7060.

87. Owen, N. E., and M. L. Villereal. 1982. Biochem. Biophys. Res. Commun. 109:762-768.

88. Owen, N. E., and M. L. Villereal. 1983. J. Cell. Physiol. 117:2329.

89. Shen, S. S., and P. Steinhardt. 1979. Nature (Lond.). 282:87-89. 90. Reuss, L., K. U. Petersen. 1985. J. Gen. Physiol. 85:409-429.

91. Kahn, A. M., G. M. Dolson, M. K. Hise, S. C. Bennet, and

E. J. Weinman. 1985. Am. J. Physiol. 248:F212-F218.

92. Sefton, B., and T. Hunter. 1984. 18:195.

93. Cooper, J. A., D. F. Bowen-Pope, E. Raines, R. Ross, and T. Hunter. 1982. Cell. 31:263-273.

93a. Grinstein, S., and A. Rothstein. 1986. J. Membr. Biol. 90:112.

94. Cohn, D. E., S. Klahr, and M. R. Hammerman. 1983. Am. J. Physiol. 245:F217-F222.

95. Tsai, C. J., H. E. Ives, R. J. Alpern, V. J. Yee, and B. G. Warnock. 1984. Am. J. Physiol. 247:F339-F343.

96. Kinsella, J. L., T. Cujdik, and B. Sacktor. 1984. Proc. Natl. Acad. Sci. USA. 81:630-634.

97. Seifter, J. L., and R. C. Harris. 1984. Kidney Int. 25:282.

98. Harris, R. C., J. L. Seifter, and B. M. Brenner. 1984. J. Clin. Invest. 74:1979-1987.

99. Kinsella, J. L., J. M. Freiberg, and B. Sacktor. 1985. Am. J. Physiol. 248:F233-F239.

100. Kinsella, J. L., and B. Sacktor. 1984. Fed. Proc. 43:633.

101. Walsh-Reitz, M. M., H. N. Aithal, and F. G. Toback. 1984. Am. J. Physiol. 247:C321-C326.

102. Booth, I. W., H. Murer, G. Stange, T. R. Fenton, and P. J. Milla. 1985. Lancet. i:1066-1069.

103. Hilton, P. J. 1986. N. Engl. J. Med. 314:222-229.

104. Weder, A. B. 1986. N. Engl. J. Med. 314:198-201.

105. Deitmer, J. W., and D. Ellis. 1980. J. Physiol. 304:471-488.

106. Moody, W. J. Jr. 1981. J. Physiol. 316:293-308.

107. Baroin, A., F. Garcia-Romeu, T. Lamarre, and R. Motais. 1984.

J. Physiol. 356:21-31.

108. Sapirstein, V. S., and D. J. Benos. 1984. J. Neurochem. 43: 1098-1105.

109. Benos, D. J., and V. S. Sapirstein. 1983. J. Cell. Physiol. 116: 213-220.

110. Cohn, D. E., K. A. Hruska, S. Klahr, and M. R. Hammerman. 1982. Am. J. Physiol. 243:F293-299.

111. Harris, R. C., B. M. Brenner, and J. L. Seifter. 1986. J. Clin. Invest. 77:724-733.

112. Pollock, A. S., R. T. Miller, G. J. Strewler, and D. G. Warnock. 1985. Kidney Int. 27:287a. 